programmes, has so far declined to comment on the reduction in the science budget until its full impact has been assessed, although he is reported to be "extremely disappointed".

David Southwood, professor of physics at Imperial College, London, and chairman of ESA's science programme committee, describes the prospect of a 9 per cent cut over three years as a "squeeze" that can be managed. But he goes on to say that he would be worried if the level of cuts were extended beyond then, arguing that this would lead to a general attrition of the programme.

The United Kingdom, which will be in a position to veto any further increase after 1988, at present feels confident that the level funding will be extended to the full five years. Ian Corbett, director of science at the UK Particle Physics and Astronomy Research Council (PPARC), says this will result in a reduction of 15 per cent in ESA's space science budget - equivalent to a saving of $£ 15$ million for the United Kingdom that is now available for its domestic space programme - and is therefore "not much less" than the 25 per cent reduction which Britain had been seeking.

Indeed, Britain's delegation to the ministerial meeting described the outcome as a "success". According to Corbett, as well as making money available for PPARC to spend on instruments and exploiting the results of missions, the agreement will improve PPARC's ability to plan in the long term, as ESA will no longer have to find extra money each time the inflation rate changes. "The arguing is now over," says Corbett. "We and ESA have a stable basis on which to move forward."

Jean-Marie Luton, the director general of ESA, claimed during last week's meeting that the budget cuts were unlikely to have a significant impact on planned space missions. But others are less optimistic. One agency official points out that all of ESA's programmes are under financial pressure, and that the science programme could still become a target for further cuts.

Such cuts may not be made directly, but rather may emerge as the result of administrative reforms at the agency. The science programme, for example, has until now benefited from privileged charging arrangements for overheads, and these risk being trimmed back, according to Southwood.

According to Southwood, the overall challenge to the agency, and indeed to Europe's space industry in general, is to improve the efficiency with which it carries out projects. He refers in particular to proposed reforms of ESA's industrial policies, which will be reviewed at an informal ministerial meeting next year. "Industry will need to do more for less," he says. But he warns that delays - or even cuts to the science programme now seem inevitable.

D.B.

\title{
Health bodies urge backing for early warning procedures
}

Washington. The World Health Organization (WHO) and the US Centers for Disease, Control and Prevention (CDC) have appealed to their respective funding bodies for more money to pay for joint and separate initiatives to identify, control and eventually eradicate emerging infectious diseases.

The WHO has asked its 190 member states for $\$ 5.5$ million to help foot the $\$ 7$ million costs for a worldwide early warning system to pre-empt infectious diseases, citing examples such as last year's spread of bubonic plague in India which killed 54 and left losses worth an estimated $\$ 1.5$ billion, and the Ebola virus outbreak that killed 300 in Zaire. The proposals include the setting up of a network of rapid response units to place expert health teams at any world disease zone within 24 hours of an outbreak.

Meanwhile the CDC is urging the US Senate to recommend an increase in its budget to match the $\$ 125$ million annual operat-

\section{IMAGE UNAVAILABLE FOR COPYRIGHT REASONS}

First signs: rats in Surat provided indicators of the possible arrival of bubonic plague.

ing costs once the conclusions of its report, Addressing Emerging Infectious Disease Threats: A Prevention Strategy for the United States, are fully implemented, planned for the year 2002.

The WHO project will be run by its newly created Division of Emerging, Viral and Bacterial Diseases Surveillance and Control (EMC). It will be headed by David Heymann, the physician credited with stopping the spread of Ebola to 2 million people in the Zairean capital of Kinshasha.

"EMC will work to strengthen country surveillance and disease control in order that countries that develop the early warning systems necessary to detect an emerging or re-emerging disease through innovative field epidemiology and public health laboratory programmes," Heymann said last week.

The CDC project, which shares many of the WHO programme's objectives although restricted to the United States has so far received just $\$ 7.7$ million this year. The House of Representative has recommended an increase of $\$ 12.8$ million to the CDC's overall budget. But so far, the Senate has been less generous.

"History tells us that infectious diseases will remain important, evolving complex public health issues," David Satcher, the director of CDC, told a hearing of the Senate Labor and Human Resources committee last week. The main problem, he says, lies at the state and local levels, where funding cuts in health departments have left them "poorly prepared" to identify and respond to infectious agents. But Satcher added that federal agencies, led by the CDC, are well placed to deal with emerging infectious diseases both in the US and abroad.

His comments contrast with those in a 1992 report by the Institute of Medicine which criticized the nation's ability to identify and react to harmful organisms. This was seen as a clarion call for renewed effort against emerging infections.

The fact that the CDC and WHO projects share similar goals and the same lexicon - "to strengthen surveillance, strengthen prevention and control, strengthen infrastructures, foster applied research" - is no coincidence. One quarter of WHO's budget comes from the US government, and the US contribution is currently threatened with cuts of 35 per cent proposed by a Senate appropriations panel. WHO officials would dearly like to see CDC succeed in its bid for more funds. A vote for the CDC project would, by implication, be a vote for WHO.

Much of WHO's promotional literature addresses both its international as well as its US policymaker audience. In a briefing paper, Hiroshi Nakajima, WHO's director general, says the agency's strategy for tackling emerging infectious diseases "is consistent with the plan developed by the Centers for Disease Control and Prevention".

Meanwhile, a group of 17 US agencies led by the CDC, known as the Committee on International Science, Engineering and Technology, has been discussing how to upgrade the global response to threats of infection. In a report published in July, it recommends establishing a global surveillance network linking up to the CDC. A task force from this group will meet in November to produce another plan outlining how its recommendations should be implemented.

Adrianne Appel \& Ehsan Masood 